\title{
THE MEDIONIGRA POLYMORPHISM OF PANAXIA DOMINULA
}

\author{
E. B. FORD \\ Genetics Laboratories, Department of Zoology, Oxford \\ and \\ P. M. SHEPPARD \\ Department of Genetics, University of Liverpool
}

Received 10.xii.68

\section{INTRODUGTION}

Panaxia dominula is a warningly coloured day-flying moth, a member of the Hypsidae. It is widespread but with a discontinuous distribution in the southern half of England, occurring sometimes abundantly in colonies that are usually isolated from one another; for though powerful on the wing, the imagines rarely wander from the localities to which they are adapted. These are marshes and river banks where the favourite larval food plant Symphytum, the Comfrey, grows; but, rather curiously, populations of this insect have occasionally been found along relatively dry hedgerows provided they include a strip of rough herbage and a ditch with some Symphytum in it. The species has but one generation in a year and details of its ecology and habits can be obtained from Ford (1967).

The medionigra form of $P$. dominula has been studied at Cothill, Berkshire, every year from 1939 to 1968, following observations made there in 1921, 1936 and 1938. The data so obtained have been published several times as they have accumulated (Fisher and Ford, 1947; Sheppard, 1951, 1953, 1956; Ford, 1965, Chapter 7), but the last year for which they have been made available is 1961. The three phases are controlled by a single major gene. Medionigra is a heterozygote and is visibly distinct from the two homozygotes, the normal dominula and the rare bimacula. These forms have been illustrated several times (e.g. Fisher and Ford, 1947; Ford, 1965, Plate 5 (1); Sheppard, 1967, p. 31). Medionigra is variable in appearance but more closely resembles dominula than bimacula. This polymorphism of $P$. dominula is known to occur naturally in no other locality. However, artificial populations containing medionigra now exist at several places, having been founded as new colonies with material brought originally from Cothill. These have been described by Sheppard and Cook (1962) and information on their status in recent years will be given in another article. Medionigra has also been established at Sheepstead Hurst in Berkshire by another technique; that of introducing the gene into a population already in existence. It is the purpose of the present account to bring the results of studying medionigra up to date, both there and at Cothill and to discuss them.

\section{Cothill}

It will be seen from the Table in Ford, 1965, p. 113, that the numbers of $P$. dominula in this locality had declined during the last three years recorded there, from their very high value in $1958(12,000$ to 18,000$)$ to 1200 to 1600 
in 1961. It is known now that they fell further, to an extremely low level, in 1962 which persisted for the following two years. There was a slight increase in 1965 but this was not maintained in 1966 and 1967. It was only in 1968 that evidence of a rather definite numerical increase was obtained (table $1 *$ ).

TABLE 1

Captures of the dominula and medionigra forms of Panaxia dominula at Cothill, Berkshire, with estimated population-size and gene-frequency percentage of medionigra. To the total for 1939-68, 28 of the rare homozygote, bimacula must be added

$\begin{array}{lccrcc}\text { Year } & \text { Dominula } & \text { Medionigra } & \text { Total } & \begin{array}{c}\text { Population- } \\ \text { size }\end{array} & \begin{array}{c}\text { frequency } \\ \%\end{array} \\ 1962 & 22 & 1 & 23 & 216 & (2 \cdot 2) \\ 1963 & 58 & 1 & 59 & 470 & (0 \cdot 8) \\ 1964 & 31 & - & 31 & 272 & - \\ 1965 & 79 & 2 & 81 & 625 & 1 \cdot 2 \\ 1966 & 37 & - & 37 & 315 & - \\ 1967 & 50 & - & 50 & 406 & 1 \cdot 1 \\ 1968 & 128 & 7 & 412 & & \\ & 405 & 131 & 978 & \\ 1939-61 & 15,894 & 1,223 & 17,145 & & \\ 1939-68 & 16,299 & 1,230 & 17,557 & & \end{array}$

Up to 1961 the Cothill population-size had been calculated by the technique of marking, releasing and recapture. But this becomes extremely inaccurate or impossible when few or no marked insects are recaught. The yearly total of recaptures for the period in question is shown in table 2 and

TABLE 2

Numbers of marked specimens recaptured at Cothill during the period 1962-1968

$\begin{array}{cc}\text { Year } & \text { Recaptures } \\ 1962 & 1 \\ 1963 & 2 \\ 1964 & 3 \\ 1965 & 8 \\ 1966 & - \\ 1967 & 1 \\ 1968 & 7\end{array}$

it will be evident that this method could be employed only in 1965 and 1968 . The estimates so obtained are respectively 200 and 1100 . These must have standard errors almost as large as the population estimates themselves.

In order to derive alternative estimates of population-size, it can be enquired whether the number of specimens captured per season bears an approximately constant relation to population-size. It may be remarked, however, that even with something like equal effort the proportion captured may not be the same when the insect is rare as when it is common. For a relatively greater attempt may unconsciously be made to secure a specimen when very few are seen. Also, undivided attention can generally be given

* The column for the rare homozygote, bimacula, included in the earlier publications, is omitted here as that form has not been found since 1959 . 
to each individual sighted in a season of scarcity, whereas several may fly simultaneously within range of capture, only one of which can be taken, when the numbers are large.

The correlation between the yearly estimates of population-size and the proportion of insects captured (from 1941 to 1961) is just significant $\left(r_{19}=-0.46\right)$ and is negative, as would be expected from this argument. By estimating an unweighted linear regression of population-size on the number of moths captured (including the data for 1965 to 1968) it is possible to estimate the population-size for the years 1962 to 1968 . These estimates are given in table 1. Doubtless the error involved is great, but the sampling indicated that the assessment is of the correct order of magnitude. In the years in which the ten largest samples were caught (their size, of course, depends on the numbers of collectors available as well as on the populationdensity of $P$. dominula), 1612 to 966 specimens were captured per season. Yet the occasions on which the indirect estimates have to be made involved a roughly similar amount of work and produced an annual total of 59 to 23 captures.

When the population became relatively very small from 1962 onwards the medionigra gene might conceivably have been lost at Cothill by random genetic drift, since in any one year its number can hardly ever have much exceeded seven. It will be seen from table 1 that it has not been lost. It may be remarked, moreover, that the possible effects of such drift are opposed by the fact that when the number of individuals in the colony reaches a low level medionigra will still retain some selective advantage (p. 565).

It has been pointed out by Robertson (1962), that the selective advantage of a heterozygote over both homozygotes will increase the likelihood of a very rare allelomorph being lost as the result of genetic drift. However, in the present example one of the factors maintaining the polymorphism appears to be a frequency dependent selection acting on the heterozygote and not an overall advantage of this genotype at all gene frequencies (p. 565). Thus, the circumstances investigated mathematically by Robertson (1962) do not strictly apply.

\section{Sheepstead Hurst}

The Sheepstead Hurst colony of $P$. dominula was first studied by Sheppard (1956) in 1949. The numbers rose to the large total of 26,000 to 20,000 imagines in 1953 while only two years later they were as small as 5000 to 3000. The colony was not intensively studied between 1957 and 1960 . However, an attempt to collect larvae in the spring of 1958 was unsuccessful and revealed that the colony was nearly extinct. Larvae were uncommon in 1959 and it was not until 1960 that reasonable numbers of them were available for collection. Thus, the population went through a crisis similar to that at Cothill but of much shorter duration and at a different time. Despite the severe reduction of numbers at Sheepstead Hurst, again the medionigra gene introduced in 1954 was not lost (see below).

It should be noticed that the populations at Cothill and Sheepstead Hurst do not fluctuate synchronously, a fact evident both in the past and in the additional data now presented. The point has been discussed by Ford (1965, pp. 17-18).

The reason for the great reduction in numbers at Cothill after 1961 is not apparent. The size of the locality has indeed been diminished from about 
17 to 10 acres in the last 12 years. But this had occurred before the great numerical decline. The rest of the habitat has not been interfered with, while the remaining area is the one in which for 20 years or so the population has been chiefly concentrated. The decline in the Sheepstead Hurst colony was also not associated with any marked change in the size or appearance of the habitat.

By 1954 Sheppard (loc. cit.) had provided convincing evidence that medionigra was absent from Sheepstead Hurst. In the year, therefore, when the colony numbered about 10,100 imagines he scattered in it the eggs from 50 heterozygotes of Cothill origin back-crossed to dominula, so bringing the medionigra gene-frequency to about 0.2 per cent. of available loci. Two

TAble 3

Population-size of Panaxia dominula at Sheepstead Hurst, Berkshire, and percentage-frequency of the medionigra gene, first introduced into the colony in 1954. The data and results for 1962 onwards have not previously been published. Those for the earlier years are given for ease of comparison

\begin{tabular}{|c|c|c|c|c|c|}
\hline Year & Dominula & Medionigra & Total & Population-size & $\begin{array}{c}\text { Gene- } \\
\text { frequency } \%\end{array}$ \\
\hline 1949 & - & - & - & $5,000-6,000$ & - \\
\hline 1950 & - & - & - & $3,600-4,800$ & - \\
\hline 1951 & - & - & - & $4,000-6,000$ & - \\
\hline 1952 & - & - & - & $6,000-8,000$ & - \\
\hline 1953 & - & - & - & $20,000-26,000$ & - \\
\hline 1954 & - & - & - & $8,500-13,500$ & $0 \cdot 2$ \\
\hline 1955 & 873 & 2 & 875 & $3,000-5,000$ & $0 \cdot 1$ \\
\hline 1956 & 443 & 4 & 447 & $3,000-5,000$ & $0 \cdot 4$ \\
\hline 1961 & 405 & 9 & 414 & $1,500-3,500$ & $1 \cdot 1$ \\
\hline 1962 & 228 & 1 & 229 & $1,000-2,000$ & $(0 \cdot 2)$ \\
\hline 1963 & 727 & 15 & 742 & $2,000-4,000$ & 1.0 \\
\hline 1964 & 739 & 13 & 752 & $3,500-6,500$ & 0.9 \\
\hline 1965 & 1,136 & 4 & 1,140 & $6,000-8,000$ & $0 \cdot 2$ \\
\hline 1966 & 509 & 7 & 516 & $1,500-4,500$ & $0 . \overline{7}$ \\
\hline 1967 & 69 & 2 & 71 & $200-400$ & 1.4 \\
\hline 1968 & 137 & 1 & 138 & $500-1,000$ & $(0 \cdot 4)$ \\
\hline
\end{tabular}

medionigra imagines were caught the following year in a total of $875(=0 \cdot 1$ per cent.) while by 1961 the proportion had risen to $1 \cdot 1$ per cent. ( 9 heterozygotes out of 414). The size of the population and the frequency of the medionigra gene has been determined each year subsequently. These results and the data upon which they are based are now given for the first time in table 3. The earlier figures are added for comparison.

It should be mentioned that it was in $P$. dominula at Sheepstead Hurst that Kettlewell (1952) first estimated larval numbers, and late larval and pupal mortality in the Lepidoptera. He did so by marking the larvae with a radioactive tracer, Sulphur-35.

\section{Discussion}

The original object of studying the medionigra polymorphism of $P$. dominula at Cothill has been attained. That is to say, it provided a test in natural conditions to determine whether the frequency of this form fluctuates due to random genetic drift or to the effects of selection, changing in intensity and direction from year to year. For in earlier stages of the work 
random genetic drift still appeared important to some students of evolution even in a population as large as this one prior to 1962. It was, in fact, shown by Fisher and Ford (1947) that these annual frequency-variations were largely due to selection. Sewell Wright (1948) indeed made an effort to contest this view, but his criticisms were fully answered by Sheppard (1951). Not only can the changes in the frequency of the gene between 1939 and 1946 not be explained except by postulating the action of natural selection, but the subsequent frequencies also preclude the hypothesis that the selective values of the three genotypes have remained constant between 1939 and 1961. Thus not only has selection been acting but its intensity must also have been fluctuating. It may be added, as will shortly appear, that the nature of the selective advantages and disadvantages involved have now partly been determined and at least one of them is such that one must expect its intensity to vary from year to year.

We know of no wild population of any animal that has been so fully studied quantitatively as $P$. dominula at Cothill. In the course of such extensive research, it is natural that problems not initially envisaged should come to light and that information should be obtained upon them.

As a result of detailed breeding work (Sheppard and Cook, 1962), it has now been found that the survival-rate of medionigra from egg to imago is only about 75 per cent. that of homozygous dominula; so too, its male fertility is slightly but significantly reduced. Sheppard and Cook (loc. cit.) have also shown that these disadvantages are opposed by the effect of differential mating. They find that the females of each form prefer to pair with males of a different phenotype from their own. There is no corresponding effect in the males. Such a mating-preference automatically favours the rarer form and tends to preserve it as a polymorphism. This curious differential-mating is not unique; it may be compared with that between ebony and vestigial males in Drosophila melanogaster (Rendel, 1951) and other instances.

From these facts it is clear that the medionigra gene has not yet evolved an overall heterozygous advantage at Cothill. The explanation seems to be that it has not had time to do so. The reasons for thinking this polymorphism reasonably recent are these. (i) This is the only population in which it is known to exist. (ii) The medionigra has not yet evolved dominance there, although that process is in progress (p. 566).

It may be enquired why medionigra has established itself at Cothill but not in other places. This may possibly be due to the fact that the mutation has not appeared in appropriate circumstances elsewhere. Indeed, the failure to mutate to a given useful gene may in some situations force a species to meet adaptive needs in other ways, as can be instanced from the industrial melanism of the moth Gonodontis bidentata (Ford, 1968). But the Cothill habitat is a remarkable one. The soil consists of deep alkaline peat, which is of the earliest Atlantic Age almost to the surface. The ecology of this marsh is exceptional, so that it supports a fauna and flora highly unusual for south-central England. Thus one could well conceive that a form which did not succeed elsewhere might become established as a plymorphism in such circumstances.

Medionigra is decidedly variable (Ford, 1965, plate 5, i) and is not sexcontrolled. Therefore it presents evident opportunitities for rapid dominance modification. The correctness of this conclusion was easily established in the laboratory, it proved possible with only three generations of 
selection on the one hand markedly to intensify the expression of the gene, and on the other to reduce it until the heterozygotes could hardly be distinguished from the normal homozygote, dominula (Ford, unpublished). That is to say, to make the medionigra form move towards dominance in the one line and towards recessiveness in the other. The effect in the + direction was striking but did not overlap the phenotype of the rare homozygote, bimacula; for medionigra is much nearer in appearance to the common homozygote than to the rare one.

A watch has been kept to detect any comparable changes in nature and their existence has now been established. The average dimensions of the additional black spot in the centre of the hindwings characteristic of medionigra, are $1.5 \times 0.5 \mathrm{~mm}$. They have at Cothill gradually increased to about $3.0 \times 2.0 \mathrm{~mm}$.; producing, relative to the other markings, more a patch than a spot.

At Sheepstead Hurst the reverse has occurred. When a black spot on the scarlet hindwings becomes very small it is surrounded by a penumbra of yellow, indicating something of the area generally occupied by the marking. At Sheepstead Hurst the spot in question became represented by a yellow dot, in the centre of which a few black scales were present. In the last three years these latter have disappeared also, leaving only the trace of yellow in all ten of the specimens captured. That is to say, medionigra is on the point of being unrecognisable in this locality.

It is perhaps questionable if these nearly normal specimens really represent medionigra at all. The reasons for thinking that they do so are the following. (i) Selection in the "minus line" in the laboratory produced just this effect. (ii) Though the observation has been a difficult one to make, it may be said that the reduction in the expression of the medionigra gene at Sheepstead Hurst has been gradual over the years, leading down to the condition now observed. (iii) Phenotypically identical specimens from an artificial colony (at Hinskey, Sheppard and Cook, 1962) established by backcrossing medionigra into Sheepstead Hurst stock and then releasing the progeny, have been shown to produce homozygous bimacula on being crossed to a typical medionigra.

It is true, however, that we can only obtain complete proof that these almost normal individuals found at Sheepstead Hurst are in fact heterozygotes for this gene when it is possible to cross them with ordinary or extreme medionigra, or with bimacula (of which H. B. D. Kettlewell has a pure colony). This has not so far been done. But, taking everything into consideration, including the gradual establishment of the reverse effect in the other colony, it seems wrong to delay this account further, considering that it is much overdue and that the numbers at Cothill have apparently begun to rise again.

As the effect of the medionigra gene is increased in one locality and diminished in the other, there is evidently an equal probability which way the change might move in either place if due to chance alone. It is, however, worth while noting that the adjustment has been towards recessiveness where it had not established itself. If we are indeed detecting the increasing recessiveness of medionigra at Sheepstead Hurst as seems reasonably certain, and we can accept its increasing dominance at Cothill, this is perhaps the first instance in which an evolutionary change in nature has been forestalled in the laboratory. 
It is pertinent to enquire what forces are controlling these changes in dominance. The medionigra gene has been relatively common at Cothill for many years and the phenotype of the heterozygote has always been remarkably variable. It is not unlikely, therefore, that the observed change in the average phenotype has occurred as the result of natural selection favouring the more extreme examples. However, at Sheepstead Hurst the form has only been present since 1955 (after having been introduced) and not many more than 400 heterozygotes could have existed since then. Thus it seems unlikely that the increased recessiveness can be attributed to the selection of modifiers. It is more probable that the Sheepstead Hurst colony already had modifiers which tend to make the gene seem recessive in effect. This is to be expected since it has not established a stable polymorphism and if present in the past is likely only to have been maintained by recurrent mutation. The apparent gradual evolution of a degree of recessiveness over a period of 13 years further suggests that some of the modifiers increasing dominance at Cothill (introduced into Sheepstead Hurst with the gene) are linked to the medionigra locus, and have gradually become dissociated by crossing over. This might be expected in a polymorphic situation since such modifiers would be initially much more effective than unlinked ones. It will evidently be of outstanding interest to study the further stages of these evolutionary processes.

Considering the work as a whole, it is unfortunate that further information was not obtained during the first two seasons, those of 1939 and 1940. At that time it seemed necessary merely to establish initially the proportion of medionigra at Cothill so as to discover whether it had increased in frequency as it appeared to have done: an impression gained in comparison with rather casual observations in previous years. Indeed during this preliminary period, the full significance and possibilities of investigating this polymorphism did not become apparent. The data collected during the first two years were therefore defective, and in two ways.

1. Though the gene-frequency was established, total population-size was not. Indeed the method of detecting this by means of marking, release and recapture was then a novel one: it had in fact only been applied to the Lepidoptera for the first time a year previously (Dowdeswell, Fisher and Ford, 1940), and was not used in the $P$. dominula work until 1941. Since, however, the insects were flying freely in 1939 and 1940 and no difficulty was experienced in making considerable captures in a few hours, the insect was evidently common in those years, quite unlike the situation at Cothill from 1962 onwards, or even that in 1961. It was not, however, abundant to an unprecedented degree in comparison with later observations.

2. Having regard, as it transpires, to the exceptional nature of the sample in 1940, it is particularly unfortunate that this was so small, only 117 specimens. However, they were sufficient to demonstrate a quite extraordinarily large proportion of medionigra $(11 \cdot 1$ per cent.), a fact supported by its high values in the previous and succeeding seasons. The whole 1940 catch was obtained in a single day. Yet the failure to carry the work further will probably not surprise those who experienced war-time conditions in England during that summer.

There is thus an additional reason for continuing the observations on the medionigra polymorphism of $P$. dominula at Cothill. As just indicated, when the investigations started, the frequency of medionigra there was markedly 
higher than ever detected subsequently. Nothing in our later experience of the situation, or in the conclusions drawn from it, can account for this. One must hope that the events which produced it will be repeated so that they can be studied and interpreted.

\section{Summary}

1. The day-flying moth Panaxia dominula (Hypsidae) is a colony forming species. It is polymorphic at Cothill, Berkshire, for a form medionigra. This is controlled by a single pair of alleles with visibly distinct effects in all three genotypes.

2. The frequency of this gene has been studied at Cothill since 1939 and the population-size has been estimated there since 1941. These data are now published for the first time from 1962 to 1968.

3. The numbers dropped to an unprecedentedly low level in 1962 and only showed definite signs of increasing again in 1968. The medionigra form was not lost by random genetic drift during that period, despite the fact that the expected annual number of this form must have been reduced to about seven on several occasions.

4. The original object of analysing this population, to determine if variations in the medionigra frequency were due to the effects of selection rather than to random drift, has already been attained. Further investigation has revealed that the relative selective coefficients of the three genotypes cannot have been constant from year to year.

5. It has been shown that the survival-rate of medionigra is only 75 per cent. that of dominula, while its male fertility is also reduced. Such counterselection is opposed by differential mating, which gives medionigra an advantage when this form is rare, so maintaining the polymorphism.

6. Medionigra has not yet evolved heterosis, probably because it has not had time to do so.

7. When first studied at Cothill in 1939 and 1940, medionigra was much commoner than it has been subsequently, to an extent which cannot at present be interpreted. The work must be continued there in the hope that the events responsible for that situation will be repeated so that they can be analysed.

8. Cothill is the only known locality where this polymorphism occurs naturally. It has been established elsewhere by founding new colonies containing medionigra and by introducing that form into a population, at Sheepstead Hurst, where it had been shown to be absent.

9. Its frequency, together with the population-size, has been studied at Sheepstead Hurst in subsequent years. These data are now given for the first time for the period 1962 onwards.

10. It was possible to select the visible effects on the medionigra gene in the laboratory so as to make them nearly recessive in one line and to progress towards dominance in the other (the heterozygote is much nearer the normal than the rare homozygote in appearance).

11. Medionigra has now become nearly recessive at Sheepstead Hurst, where it had not established itself until introduced artificially, while its effects are becoming accentuated at Cothill where it occurs naturally. This is perhaps the first time that laboratory work has forestalled evolutionary changes in nature. 
Acknowledgments. -We should like to express our gratitude to Mr Norman D'Arcy and to the Berkshire, Buckinghamshire and Oxfordshire Naturalist's Trust, owners of different parts of Cothill Marsh, for their kind permission to carry out our investigations there. Also to those who, since 1961, have in several seasons helped us with the work of capturing and marking the specimens: Dr Lincoln Brower and DrJane Van Zant Brower, Dr L. M. Cook, Mr L. Gilbert, Mr D. R. Lees, Mr R. J. A. Metcalfe, Dr V. Scali and Mr S. Whalley.

In 1944 and 1948 respectively, Professor Ernst Mayr of Harvard and Professor Th. Dobzhansky of the Rockefeller University, New York, accompanied us and took part in the work for several days. We greatly value their interest in it.

\section{REFERENCES}

DOWDESWELl, W. H., FISHER, R. A., AND FORD, E. B. 1940. The quantitative study of populations in the Lepidoptera. Ann. Eugen. Lond., 10, 123-136.

FISHER, R. A., AND FORD, E. B. 1947. The spread of a gene in natural conditions in a colony of the moth Panaxia dominula L. Heredity, 1, 143-174.

FORD, E. B. 1965, 2nd edn. Ecological Genetics. Methuen, London.

FORD, E. B. 1967, 2nd edn. Moths. Collins, London.

FORD, E. B. 1968. Ecological genetics. Adv. Sci., 25, 227-235.

KETTLEWELL, H. B. D. 1952. The use of radioactive tracers in the study of insect populations. Nature, $170,584$.

RENDEL, J. M. 1951. Mating of ebony vestigial and wild type Drosophila melanogaster in light and dark. Evolution, 5, 226-230.

ROBERTSON, A. 1962. Selection for heterozygotes in small populations. Genetics, 47, 1291 1300.

Sheppard, P. M. 1951. A quantative study of two populations of the moth, Panaxia dominula (L.). Heredity, 5, 349-378.

SHEPPARD, P. M. 1953. Polymorphism and population studies. Symposia Soc. Exp. Biol., No. 7, 274-289.

Sheppard, P. м. 1956. Ecology and its bearing on population genetics. Proc. Roy. Soc. B, $145,308-315$.

SHEPPARD, P. M. 1967, 3rd edn. Natural Selection and Heredity. Hutchinson, London.

SHEPPARD, P. M., AND COOK, L. M. 1962. The manifold effects of the medionigra gene in the moth Panaxia dominula and the maintenance of a polymorphism. Heredity, 17, 415-426.

WRIGHT, s. 1948. On the roles of directed and random changes in gene frequency in the genetics of populations. Evolution, 2, 279-294. 